\title{
Energy balance and cost analysis for raisin production in Aegean Region in Turkey
}

\author{
Hülya Uysal ${ }^{1}$ and Gamze Saner ${ }^{2}$ \\ ${ }^{1}$ Viticulture Research Institute, Department of Agricultural Economics, Manisa, Turkey \\ ${ }^{2}$ Aegean University, Department of Agricultural Economics, Faculty of Agriculture, Izmir, Turkey
}

\begin{abstract}
The aim of this study is to determine energy consumption of input and output used in raisin production and making a cost analysis in Aegean Region. Energy output-input analysis is generally done to determine the scope of environment and energy efficiency of agricultural production. In this study the cost of raisin production was calculated by Manisa Viticulture Research Institute's records in 2015. Costs of inputs and prices of raisin were obtained from various sources such as Turkish Statistical Institute, Aegean Exporters' Association and Turkish Ministry of Food, Agriculture and Livestock. The total energy input necessity for raisin production was $39,066.91 \mathrm{MJ} / \mathrm{ha}$. The research results indicated that the total energy input used for raisin was mainly dependent on non-renewable energy forms (\%97). The high ratio of non-renewable energy in the total used energy inputs causes negative effects on the sustainability in agricultural production. Among input energy sources, diesel oil, chemical fertilizers and electricity contained highest energy shares with $34.30 \%, 26.96 \%$, and $22.50 \%$ respectively. The energy ratio and energy productivity were found to be 6.04 and $0.51 \mathrm{~kg} / \mathrm{MJ}$. Gross production value and total variable costs for raisin were $\$ 8,600$ and $\$ 4,528.25$, respectively. As a result of cost analysis, gross margin was calculated as $\$ 4,071.75$.
\end{abstract}

\section{Introduction}

A wide variety of grapes can be grown in Turkey because of its climatic conditions and good soil structure. The most important grape variety grown in Turkey is Sultana (seedless white grape variety). Sultana variety is the main variety for raisin. It is grown in Aegean Region especially in Manisa, Alaşehir, Salihli, Turgutlu, Akhisar, Menemen, Kemalpasa, Cal and Civril. Turkey's raisin production is 196,000 tons in 2015 and with this figure $17 \%$ of total world raisin production. Turkey is the largest raisin exporter in the world with 175,000 tons [1].

The relation between agriculture and energy is very close. Agriculture itself is an energy user and energy supplier in the form of bio-energy. Efficient use of energy resources is vital in terms of increasing production, productivity, competitiveness of agriculture and sustainability of rural living. Improving the energy efficiency not only helps in improving competitiveness through cost reduction but also results in minimized energy-related environmental pollution, thus positively contributing towards sustainable development.

The energy input-output analysis is usually made to evaluate the efficiency and environmental impacts of production systems. In recent years, many researchers have investigated the energy use for agricultural production. In some studies the effect of farm size on energy use efficiency of agricultural production was investigated; Esengun et al. examined the dry apricot production in different farm sizes in terms of energy use efficiency and economic analysis [2]. They reported that, both the total energy input and output energy in apricot production decreased when farm size increased; while, the energy use efficiency and energy productivity increased when farm size increased. Yilmaz et al. investigated the effect of farm size on energy use and input costs for cotton production in Turkey; from this study it was found that large farms were more successful in energy productivity, use efficiency and economic performance; also, it was concluded that energy management at farm level could be improved to give more efficient and economic use of energy [3]. Cetin and Vardar investigated the energy consumption in small, medium and large size of tomato farms; they concluded that large size farms were more successful in terms of energy use and economic performance [4].

\section{Materials and methods}

The amount of inputs used in the production of raisin and output (grape yield) were calculated per hectare and then multiplied by the coefficient of energy equivalent. Energy equivalents of inputs and output were converted into energy per unit area (Table 1).

Energy equivalents of inputs and outputs for raisin were obtained from a number of different studies about relevant subjects. [5-8].

Energy equivalent for machinery was calculated using Eq.

$$
M E=\frac{E G}{T}
$$

where:

$\mathrm{ME}$ is the machinery energy $(\mathrm{MJ} / \mathrm{h})$

$\mathrm{E}=(62.7 \mathrm{MJ} / \mathrm{kg})$ is the equivalent energy for machinery production

$\mathrm{G}$ is the weight of machine $(\mathrm{kg})$

$\mathrm{T}$ is the economic life of machine $(\mathrm{h})$. 
Table 1. Energy equivalents of inputs and output in agricultural production.

\begin{tabular}{|l|l|c|l|}
\hline \multicolumn{2}{|l|}{ Inputs (unit) } & $\begin{array}{l}\text { Energy } \\
\text { equivalent (Mj/unit) }\end{array}$ & Reference \\
\hline Human Labour (h) & & 1.96 & Sing et al. (2002) \\
\hline Machinery (h) & & 13.06 & Özkan et al. (2004) \\
\hline \multirow{3}{*}{$\begin{array}{l}\text { Chemicals } \\
\text { [fertilizers (kg)] }\end{array}$} & Nitrogen & 6060 & Sing et al. (2002) \\
\cline { 2 - 4 } & Phosphorus & 11.1 & Sing et al. (2002) \\
\cline { 2 - 4 } & Potassium & 6.7 & Sing et al. (2002) \\
\hline \multirow{3}{*}{$\begin{array}{l}\text { Chemicals } \\
\text { (Pesticide [kg]) }\end{array}$} & İnecticide & 199 & Helsel (1992) \\
\cline { 2 - 4 } & Fungicides & 92 & Helsel (1992) \\
\cline { 2 - 4 } & Herbicides & 238 & Helsel (1992) \\
\hline Diesel-oil (lt) & & 56.31 & Sing et al. (2002) \\
\hline Electricity (kwh) & & 10.59 & Acaroğlu and \\
& & & Aksoy (2005) \\
\hline Water for irrigation $\left(\mathrm{m}^{3}\right)$ & 11.8 & Sing (2002) \\
\hline Output (Grape-kg) & & &
\end{tabular}

Table 2. Amounts of inputs and output with their equivalent energy in raisin production.

\begin{tabular}{|c|c|c|c|c|}
\hline INPUTS & & $\begin{array}{l}\text { Quantity } \\
\text { per unit } \\
\text { area (ha) }\end{array}$ & $\begin{array}{l}\text { Total energy } \\
\text { equilavent }(\mathrm{MJ})\end{array}$ & $\%$ \\
\hline \multirow{5}{*}{ Human labour (h) } & Land preparation & 32 & 62.72 & 0.16 \\
\hline & Cultural practises & 319.2 & 625.63 & 1.60 \\
\hline & Harvesting & 160 & 313.60 & 0.80 \\
\hline & Drying practises & 180 & 352.80 & 0.90 \\
\hline & Total & 691.2 & 1354.75 & 3.47 \\
\hline \multirow{4}{*}{ Machinery (h) } & Land preparation & 32 & 417.92 & 1.07 \\
\hline & Cultural practises & 80 & 1044.80 & 2.67 \\
\hline & Transportation & 16 & 208.96 & 0.53 \\
\hline & Total & 128 & 1671.68 & 4.28 \\
\hline \multirow{4}{*}{$\begin{array}{l}\text { Chemical } \\
\text { fertilizers }(\mathrm{kg})\end{array}$} & Nitrogen & 140 & 8484 & 21.72 \\
\hline & Phosphorus & 100 & 1110 & 2.84 \\
\hline & Potassium & 140 & 938 & 2.40 \\
\hline & Total & 380 & 10532 & 26.96 \\
\hline \multirow{4}{*}{$\begin{array}{l}\text { Chemical } \\
\text { Pesticide (kg) }\end{array}$} & Insecticide & 7 & 1393 & 3.57 \\
\hline & Fungucides & 6 & 552 & 1.41 \\
\hline & Herbicides & 1 & 238 & 0.61 \\
\hline & Total & 14 & 2183 & 5.59 \\
\hline Diesel oil (l) & & 238 & 13401.8 & 34.30 \\
\hline Electricity (kwh) & & 830 & 8789.7 & 22.50 \\
\hline $\begin{array}{l}\text { Water for } \\
\text { irrigation }\left(\mathrm{m}^{3}\right)\end{array}$ & & 1800 & 1134 & 2.90 \\
\hline \multicolumn{2}{|c|}{ Total energy input (MJ) } & & 39066.9 & 100.00 \\
\hline Yield (kg) & & 20000 & 236000 & \\
\hline \multicolumn{2}{|c|}{ Energy output-input ratio } & & 6.04 & \\
\hline $\begin{array}{l}\begin{array}{l}\text { Specific } \\
(\mathrm{MJ} / \mathrm{t})\end{array} \\
\end{array}$ & & & 1953.35 & \\
\hline \multicolumn{2}{|c|}{ Energy productivity (kg/MJ) } & & 0.51 & \\
\hline
\end{tabular}


The energy inputs were divided into direct and indirect with renewable and non-renewable energy forms Direct energy consisted of human labour, diesel oil and electricity; whereas, indirect energy included machinery, chemical fertilizers and pesticide. On the other hand, renewable energy consists of human labour and nonrenewable energy includes machinery, diesel oil, chemical fertilizers, pesticides and electricity [6,9].

In this study, output-input ratio, specific energy and energy productivity for raisin production were also calculated using the following equations in addition to exploring output-input energy and different forms of energy $[10,11]$.

$$
\begin{gathered}
\text { Energy ratio }=\frac{\text { Energy output }(\mathrm{MJ} / \mathrm{ha})}{\text { Energy input }(\mathrm{MJ} / \mathrm{Ha})} \\
\text { Energy productivity }=\frac{\text { Grape output }(\mathrm{MJ} / \mathrm{ha})}{\text { Energy input }(\mathrm{MJ} / \mathrm{Ha})} \\
\text { Energy ratio }=\frac{\text { Energy input }(\mathrm{MJ} / \mathrm{ha})}{\text { Raisin output }(\mathrm{MJ} / \mathrm{Ha})} .
\end{gathered}
$$

Variable costs of raisin production were calculated. This cost included labour, machinery and material costs. Variable costs were paid directly by farmers. To calculate of total gross production value of raisin production, the sale price of raisin received by farmers was multiplicated with total raisin amount. In the calculation of the gross margin of raisin, total variable costs were subtracted from total gross production value [11].

\section{Results and discussion}

Table 2 shows the amounts of inputs and output with their equivalent energy in raisin production. The total energy requirements for producing the raisin were 39,066.91 MJ/ha. Use of the diesel oil was 13,401.8 MJ/ha. Of all the inputs, the diesel oil have the highest share of $34.30 \%$ in the total energy. The second highest share in energy consumption belongs to the chemical fertilizers $(26.96 \%)$. Chemical fertilizer is followed by electricity (22.50\%), and chemical pesticide $(5.59 \%)$, respectively. The consumption of human labour and water for irrigation were $3.47 \%$, and $2.90 \%$, respectively, of the total energy input used for raisin production. The energy (output-input) ratio, energy productivity, and specific energy for Sultana production were calculated to be $6.04 \mathrm{MJ}, 0.51 \mathrm{~kg} / \mathrm{MJ}$ and 1953.35 MJ/t, respectively.

The average total energy consumed for raisin production was calculated as $39067 \mathrm{MJ}$ per hectare.

The direct energy ratio in raisin production is very high $(60.27 \%)$.

Based on energy sources, diesel oil was the main contributor of direct energy with $13401.78 \mathrm{MJ} / \mathrm{ha}$ $(34.30 \%)$, and fertilizer recording the highest indirect energy consumption of $10,532 \mathrm{MJ} / \mathrm{ha}(26.96 \%)$, as shown in Table 3.

Similar results can be seen in Koctürk and Engindeniz found that share of direct, indirect and non-renewable energy used in the total energy was $57.2 \%, 42.8 \%$ and $97.03 \%$, respectively. In a study carried out in Iran related with grapes, fertilizer rank first in energy usage [12]. In another study about in Berisso Region, Argentina, energy

\begin{tabular}{|c|c|c|c|}
\hline & & $\begin{array}{l}\text { Total energy } \\
\text { input }(\mathrm{MJ} / \mathrm{ha})\end{array}$ & $\%$ \\
\hline \multirow{3}{*}{$\begin{array}{l}\text { Energy forms } \\
(\mathrm{MJ} / \mathrm{ha})\end{array}$} & Direct energy & 23546.232 & 60.27 \\
\hline & $\begin{array}{l}\text { Indirect } \\
\text { energy }\end{array}$ & 15520.68 & 39.73 \\
\hline & Total & 39066.912 & 100.00 \\
\hline \multirow{3}{*}{$\begin{array}{l}\text { Energy forms } \\
(\mathrm{MJ} / \mathrm{ha})\end{array}$} & $\begin{array}{l}\text { Renewable } \\
\text { energy }\end{array}$ & 1354.752 & 3.47 \\
\hline & $\begin{array}{l}\text { Non- } \\
\text { renewable } \\
\text { energy }\end{array}$ & 37712.16 & 96.53 \\
\hline & Total & 39066.912 & 100.00 \\
\hline
\end{tabular}

Table 3. Total Energy Consumption Distributed by Energy Sources.

efficiency (energy-output- input ratio) was determined in vineyard system which was planted in a different way depending on the old and new system. Total energy usage in old and new vineyard systems varied between $2,740.43$ and 6,133.26 MJ/ha [13]. In a study carried out in Iran related with grapes, fertilizer ranks first in energy usage energy value of used factors and input in grape gardens of Urmia and Sardasht were 6,417,773 and 862,570 kcal/ha, respectively. Energy efficiency values (output/input ratio) were 3.99 and 11.7 respectively [12].

\section{Gross margin of raisin production}

The variable costs and gross production value of raisin production is given in Table 4 . The results reveal that the variable costs for raisin production is $4528.25 \mathrm{US} \$ / \mathrm{ha}$. The biggest share for variable costs are labour and machine $(73.33 \%)$, soil tillage (19.98\%), drying operations (16.23), pesticide $(9.28 \%)$ and fertilizer $(7.73 \%)$. However, these figures can change depending on the climatic conditions and variation in input prices each year. The average price received by the producer is $1.72 \mathrm{US} \$ / \mathrm{kg}$ and average yield of raisin for hectare is $5000 \mathrm{~kg}$. Therefore, gross production value of raisin production is $8600 \mathrm{US} \$ / \mathrm{ha}$. Then by subtracting variable costs from gross production value, gross margin from raisin production was calculated. Gross margin of raisin production was determined as 4071.75 US\$/ha.

Costs of raisin production and gross production values were put forward with a number of preceeding studies. For example, a study done in Antalya of Turkey, showed that the total costs for grape production was 3,368.60 US\$/ha. Variable costs have $41.82 \%$ of the total cost. In the same research, gross production value of grape production was found to be $7,460.60 \mathrm{US} \$ /$ ha [14]. In another research in Izmir and Manisa of Turkey, total costs for grape production was $879.30 \mathrm{US} \$ /$ ha [15].

\section{Conclusion}

The total energy consumption in raisin production was $39066.91 \mathrm{MJ} / \mathrm{ha}$. Diesel oil, chemical fertilizers and 
Table 4. Variable costs and gross margin for raisin production (US\$/ha).

\begin{tabular}{|c|c|c|c|c|}
\hline Operations & $\begin{array}{l}\text { Operation } \\
\text { time and } \\
\text { numbers }\end{array}$ & $\begin{array}{l}\text { Unit } \\
\text { cost }\end{array}$ & $\begin{array}{l}\text { Total } \\
\text { Cost } \\
(\$ / h a)\end{array}$ & $\begin{array}{l}\% \text { of } \\
\text { costs }\end{array}$ \\
\hline \multicolumn{5}{|c|}{ Culturel Operations } \\
\hline Soil tillage & $\begin{array}{l}\text { December- } \\
\text { July (6) }\end{array}$ & 150 & 900 & 19.88 \\
\hline Prunning & $\begin{array}{l}\text { December- } \\
\text { February (1) }\end{array}$ & 300 & 300 & 6.63 \\
\hline $\begin{array}{l}\text { Transport of } \\
\text { prunning } \\
\text { waste }\end{array}$ & $\begin{array}{l}\text { December- } \\
\text { February (1) }\end{array}$ & 175 & 68.25 & 1.51 \\
\hline $\begin{array}{l}\text { Branch } \\
\text { binding }\end{array}$ & $\begin{array}{l}\text { December- } \\
\text { February (1) }\end{array}$ & 175 & 87.5 & 1.93 \\
\hline $\begin{array}{l}\text { Green } \\
\text { prunning }\end{array}$ & May-June (1) & 175 & 131.25 & 2.90 \\
\hline Fertilizing & $\begin{array}{l}\text { November- } \\
\text { March (2) }\end{array}$ & 175 & 43.75 & 0.97 \\
\hline Spraying & $\begin{array}{l}\text { February- } \\
\text { July (8) }\end{array}$ & 75 & 600 & 13.25 \\
\hline Irrigation & May-July (3) & 175 & 105 & 2.32 \\
\hline Harvesting & $\begin{array}{l}\text { August- } \\
\text { September }\end{array}$ & 175 & 350 & 7.73 \\
\hline $\begin{array}{l}\text { Drying Oper- } \\
\text { ations }\end{array}$ & $\begin{array}{l}\text { August- } \\
\text { September }\end{array}$ & 300 & 735 & 16.23 \\
\hline Total & & & 3320.75 & 73.33 \\
\hline \multicolumn{5}{|l|}{ Inputs } \\
\hline & 0.7 & 350 & 7.73 \\
\hline \multicolumn{2}{|c|}{$\begin{array}{l}\text { Pesticide }+ \text { Fungucides } \\
+ \text { Herbicides }\end{array}$} & 30 & 420 & 9.28 \\
\hline \multicolumn{2}{|c|}{$\mathrm{K} 2 \mathrm{CO} 3$} & 2.5 & 125 & 2.76 \\
\hline \multicolumn{2}{|l|}{ Olive oil } & 3.5 & 35 & 0.77 \\
\hline \multicolumn{2}{|c|}{ Water } & 75 & 75 & 1.66 \\
\hline \multirow{2}{*}{\multicolumn{2}{|c|}{ Electricity (kwh) }} & 0.27 & 202.5 & 4.47 \\
\hline & & & 1207.5 & 26.67 \\
\hline \multicolumn{2}{|c|}{ Total variable costs } & & 4528.25 & 100.0 \\
\hline \multicolumn{2}{|c|}{$\begin{array}{l}\text { Average yield of raisin } \\
(\mathrm{kg} / \mathrm{ha})\end{array}$} & & 5000 & \\
\hline \multicolumn{2}{|c|}{ Producer price of raisin $\$ / \mathrm{kg}$} & & 1.72 & \\
\hline \multicolumn{2}{|c|}{ Gross production value } & & 8600 & \\
\hline \multicolumn{2}{|c|}{ Gross margin } & & 4071.75 & \\
\hline
\end{tabular}

electricity were found the highest energy consumers among all energy sources. Energy ratio was calculated as 6.04 , indicating the efficiency use of energy in the raisin production. The share of non-renewable energy for raisin production was $96.53 \%$. As a result, a reduction in the total non-renewable energy ratio, specifically in fertilizer usage would have positive effects on the sustainability of raisin production as well as other positive environmental effects.

\section{References}

[1] http://www.faostat.fao.org (2015)

[2] K. Esengun, O. Gunduz, G. Erdal, Conversion \& Management, 48(2), 592-598 (2007)

[3] I. Yilmaz, H. Akcaoz, B. Ozkan, Renew. Energy 30(2), 145-155 (2005)

[4] B. Çetin, A. Vardar, Renew. Energy 33(3), 428-433 (2008)

[5] O. Yaldiz, H. H. Ozturk, Y. Zeren, A. Bascetincelik, 5th International Congress of Agricultural Machinery and Energy, 12-14 October, Kusadas1. Turkey (1993)

[6] J.M. Singh, On farm energy use pattern in different cropping systems in Haryana India, Master of Science Thesis (Unpublished), International Institute of Management University of Flensburg, Germany (2002)

[7] B. Ozkan, H. Akcaoz, C.F. Karadeniz, Energy Conversion \& Management. 45: 1821-1830 (2004)

[8] M. Acaroglu, A.S. Aksoy, Biomass Bioenergy; 29(1): 42-48 (2005)

[9] K.G. Mandal, K.P. Saha, P.K. Ghosh, K.M. Hati, K.K. Bandyopadhyay, Biom. Bio energy. 23: 33-45 (2002)

[10] S.A. Hatirli, B. Ozkan, C. Fert, Renew Energ, 31:427-438 (2006)

[11] M. Koctürk, S. Engindeniz, African Journal Agric Res; 4 (10):938-943 (2009)

[12] A.G. Hassanzadeh, N.O. Nemati, F. Faghenaby, F. Talat, M. Mojarrad, R. Amirnia, H. Salhzadeh, J. Biol. Sci. 3: 1090-1093 (2008)

[13] E.A. Abbona, S.J. Sarandon, M.E. Marasas, M. Astier, Ecosyst. Environ. 119: 335-345 (2007)

[14] B. Ozkan, A. Kuklu, H. Akcaoz, Energy. 32: 1500-1504 (2007)

[15] Z. Bayramoğlu, E. Gundogmus, J. Agric. Res. 6: 3-11 (2008) 